\title{
Oral toxicity of essential oils and organic acids fed to honey bees (Apis mellifera).
}

\author{
Timothy A Ebert ", Peter G Kevan ", Bert L Bishop ${ }^{3}$, Sherrene D Kevan ${ }^{2}$, and Roger A Downer' \\ 'Laboratory for Pest Control Application Technology, Ohio Agricultural Research and Development Center, The Ohio State University, \\ I 680 Madison Ave. Wooster, OH 4469I, USA. \\ 2Enviroquest Ltd., 352 River Road, Cambridge, ON N3C 2B7, Canada. \\ ${ }^{3}$ Computing and Statistical Services, Ohio Agricultural Research and Development Center, The Ohio State University, I 680 Madison \\ Ave. Wooster, OH 4469I, USA.
}

Received 27 March 2007, accepted subject to revision 8 June 2007, accepted for publication 17 June 2007.

*Corresponding author. Email: tebert@ufl.edu

\section{Summary}

Natural plant products have been studied for potential use as in-hive fumigants for suppression of parasitic mites and other pests. A more direct application through direct feeding of bees would avoid problems with fumigant volatility in cold climates and provide a more systemic route of exposure for the target pest. However, there must be a balance between toxicity to hive pests and toxicity (safety) to the bees. We focused on adult bee toxicity when testing ten products: cineole, clove oil, formic acid, marjoram oil, menthol, oregano oil, oxalic acid, sage oil, thymol, and wintergreen. Each product was tested at several concentrations in a sugar syrup fed to bees over several days, and dead bees were counted daily. Oxalic acid was the most toxic of the products tested. Menthol and cineole had mortality levels no different from controls fed plain syrup after 8 days of treatment. At 14 days of treatment, wintergreen was the least toxic, but neither menthol nor cineole were a part of the testing that went to I4 days. Our results indicate that the tested products could all be used safely for treating bees orally if dose is carefully managed in the hive.

\section{Toxicidad oral de aceites esenciales y ácidos orgánicos en la alimentación de la abeja de la miel (Apis mellifera)}

Los productos naturales de plantas han sido estudiados para su uso potencial como agentes fumigantes de represión de ácaros parásitos y otras plagas. Una aplicación más directa a través de la alimentación de las abejas evitaría problemas como la volatilidad de los fumigantes en climas fríos y proporcionaría una vía más sistémica de exposición para las plagas. Sin embargo, debe haber un equilibrio entre la toxicidad para las plagas y la toxicidad (seguridad) para las abejas. Nosotros nos hemos centrado en la toxicidad sobre abejas adultas de diez productos: eucaliptol, aceite de clavo, ácido fórmico, aceite de mejorana, mentol, aceite de orégano, ácido oxálico, aceite de salvia, timol y aceite esencial de wintergreen (salicilato de metilo). Cada producto fue probado con diferentes concentraciones en un jarabe de glucosa que alimentó a las abejas durante varios días, las abejas muertas fueron contadas diariamente. El ácido oxálico fue el producto más tóxico de todos los analizados. El mentol y el eucaliptol presentaron niveles de mortalidad similares a los controles, que fueron alimentados únicamente con jarabe después de 8 días de tratamiento. Tras 14 días de tratamiento, el aceite esencial wintergreen fue el menos tóxico, pero ni el mentol ni el eucaliptol se incluyeron en el análisis a los 14 días. Nuestros resultados indican que todos los productos testados pueden ser utilizados con seguridad por vía oral para el tratamiento de las abejas si la dosis es administrada cuidadosamente en la colmena.

Keywords: Medicaments, oral toxicity, natural plant products, mortality, miticides, protectants 


\section{Introduction}

Various essential oils and organic acids have been evaluated as materials to manage mite populations afflicting honey bees. In general, these products are proposed to be used as in-hive fumigants (Imdorf et al. 1999) or as contact treatments (Amrine et al. 1996). In-hive fumigants have the disadvantage of needing warmth for sublimation or evaporation, and therefore they are less effective in colder weather (Scott-Dupree \& Otis 1992).

Nevertheless, organic acids like formic acid, and essential oils like thymol, have been found to be effective in management against mite pests in honey bee hives (Imdorf et al. 1999). Oral application circumvents the problems of fumigation in cold weather, but this application strategy has been mostly neglected. Menthol can be administered orally to honey bees, in microencapsulated formulation, with beneficial effects in suppressing population growth of tracheal mites (Acarapis woodi) (Kevan et al. 1997;2003). If essential oils and organic acids are to be considered as potential medicaments, rather than fumigants, one must be sure that the target animals (e.g. honey bees) are not poisoned. As with the research on menthol, we investigated oral toxicity of various essential oils and organic acids with the aim of assessing the potential problem of poisoning the patients with the active ingredient of the medicine (Kevan et al. 1999). As a control, we also used a plant compound, amygdalin, known to be poisonous to honey bees (Kevan \& Ebert 2005), and reassessed menthol as a compound known to be innocuous to honey bees (Kevan et al. 1999). Menthol provides a positive control that is useful in evaluating the toxicity of other medicaments.

This research was on the toxicity of various natural plant compounds to honey bees with the intent to use these compounds to treat hives for various hive pest problems. It is likely that such treatments will involve exposing the colony to the compound for weeks or months. It is therefore necessary to assess how both the dose and the length of exposure influence mortality.

\section{Materials and Methods}

Honey bees (Apis mellifera ligustica) were obtained from hives at the Ohio Agricultural Research and Development Center (OARDC) Honey bee Lab, and placed in cages similar to those used by Kulencevic \& Rothenbuhler (1973), and previously described in Kevan \& Ebert (2005). Each cage had an average of 48 bees (+/- 15 S. D.; range 20-134). Fed bees were given sugar syrup (69\% sucrose), or a $69 \%$ sucrose syrup spiked with one of 10 possible natural plant products: cineole (CAS 470-82-6), clove oil, formic acid (CAS 64- | 8-6), marjoram, L-menthol (CAS 22165।-5), DL-menthol (CAS 1490-04-6), oregano oil, oxalic acid (CAS 144-62-7), sage oil, thymol (CAS 89-83-8), or natural wintergreen oil (CAS | 19-36-8). The clove oil was a commercial extract from Eugenia caryophyllata Thunb. (Myrtaceae). The main chemical components of clove oil are eugenol, eugenol acetate, iso-eugenol and caryophyllene (http://www.essentialoils.co.za/essential-oils/clove.htm). The oregano oil was a commercial extract from Origanum vulgare L. (Lamiaceae). The main chemical components are carvacrol, p-cymene, y-terpinene, and b-caryophyllene (Chorianopoulos et al. 2004). The marjoram oil was a commercial extract from Origanum marjorana L. (Lamiaceae). The main chemical constituents are sabinene, a-terpinene, $y$-terpinene, p-cymene, terpinolene, linalool, cis-sabinene hydrate, linalyl acetate, terpinen4-ol and y-terpineol (http://www.essentialoils.co.za/essentialoils/marjoram.htm). The sage oil was a commercial extract from Salvia sclarea L. (Lamiaceae). The main chemical components of sage oil are linalool, a-terpenol, linalyl acetate, neryl acetate, and sclareol (Pitarokill et al. 2002). All solutions, including the control, had $5 \mathrm{ml}$ ethanol added to bring the total syrup volume to $100 \mathrm{ml}$ Insoluble potential medicaments were dissolved in the ethanol first, then mixed with the syrup to bring the volume up to $100 \mathrm{ml}$. In addition to these treatments, we included an unfed control, with no food or water. The starvation treatment was necessary because it was rumored that some of these medicaments would reduce feeding. We needed a starvation treatment to differentiate between toxicity and death due to starvation or dehydration.

Bees were fed ad libitum for the duration of the experiments. No additional water was provided, except what they could get by feeding on the syrup solution. We will call this days of treatment (DOT), since the bees are continually exposed for the entire duration. Each treatment was replicated four times. Mortality was checked daily, and dead bees were removed. Bees were considered dead when they would no longer move in response to poking with forceps. At the end of the experiment, the live bees were frozen and then counted. Cages were kept in open laboratory conditions that ranged from 17 to $25^{\circ} \mathrm{C}$ with a R.H. (Relative Humidity) from 18 to $37 \%$.

We present the results from two tests. The first test evaluated the toxicity of all potential medicaments every day over an 8 day period at concentrations of 100 and 1000 ppm. The second test evaluated the toxicity of clove oil, formic acid, oxalic acid, oregano oil, and sage oil along with a fed and a starved control over a 14 day period. Potential medicament concentrations in the second test were at 100,500, 1000, 5000, 10000 , and 100000 ppm. Note; the 100000 ppm solutions for all potential medicaments tended to separate, or crystals developed in the solution. It is likely that the bees never experienced a potential medicament at 100000 ppm, even though we tried mixing the potential medicament back into the sugar syrup by shaking up the bottles once per day. Also note that we tested both $\mathrm{D}$ and $\mathrm{DL}$ menthol because sometimes a particular isomer is more toxic than others. However, we could not find any evidence of such a difference in the toxicity of these products. Therefore, our discussion of menthol will be the results from the combined data of the L-menthol and DL-menthol treatments.

Data were analyzed in SAS using a time-dose-mortality analyses and probit analyses. The time-dose-mortality model was a complimentary log-log model using a SAS program that was written as an implementation of the work by Priesler \& Robinson (1989). However, the Hosmer-Lemeshow goodness-of-fit test (Nowierski et al. 1996) was highly significant for all models. We suggest that this lack-of-fit was caused by long tails in the data. When individual time intervals were of special interest, we used 
Proc Probit to estimate the LD50 values for that day. Although the Proc Probit corrected for control mortality, the results from the time-dose-mortality analysis did not correct for control mortality. For this reason, the time-dose-mortality analysis overestimates the toxicity of these products.

\section{Results}

We have included the results from the amygdalin (known to be toxic to honey bees) trials for comparison (Kevan \& Ebert 2003). Relative to amygdalin, all of the materials we tested were innocuous. Although oxalic acid is quite toxic relative to the other materials (Table 1), Table 2 shows it to be somewhat less than half as toxic as amygdalin on a molecule per molecule basis.

Starved bees do not live long, with 40\% dying in the first 24 $\mathrm{H}$, and all the bees dead within four days (Table I). No other treatment had higher first day mortality rates. High concentrations of oxalic acid were the most toxic treatment, and differed from the starvation treatment by having relatively low first day mortality. Mortality was 100\% at the highest oxalic acid concentration, but bees at the lowest concentration only had about $60 \%$ mortality after 14 days (there was $40 \%$ mortality in the controls by this time). The second most toxic was formic acid, for which the last survivors died eight days post treatment at the highest concentration tested. However, mortality was only $30 \%$ after 14 days at the lowest concentration. A few other potential medicaments also showed high mortality levels at the maximum concentration tested. In contrast to these products, we conclude that cineole, menthol, marjoram, and thymol are non-toxic to bees because their mortality levels never exceeded background mortality at any concentration tested (Table 2).

All products tested were much less toxic than amygdalin on a molecular basis. Although the $\mathrm{LT}_{50}$ for oxalic acid and amygdalin are similar, it takes over twice the number of molecules of oxalic acid to achieve an equivalent level of toxicity (Table 2). However, when comparing LD $\mathrm{L}_{50}$ at 8 days of treatment (DOT), oxalic acid appears more toxic (Table 3 ). The reason the model is nonsignificant $(\alpha \leq 0.0 \mathrm{I})$ in this case is because mortality in all treatments was too high and too variable (average mortality in lowest dose was $50 \%+/$ - $40 \%$ S. D.). The reason the model for sage is also non-significant $(\alpha \leq 0.0 \mathrm{I})$ is because, even at the highest dose, mortality was only $60 \%+/-40 \%$ S. D.

The critical feature in the potential utility of all these products is their long term effects on bee health. This was assessed by keeping bees in the cages as long as possible. Treatment with sage oil resulted in highly variable mortality, for which we have no explanation. Oxalic acid, with the lowest LD 50 value, was most toxic and wintergreen was the least (Table 4).

All LDso levels decline over time. However, most show a rapid decline in $L_{50}$ values within the first few days, followed by a leveling off. In part this trend reflects ever increasing levels of background mortality. However, most cages of bees had a few individuals that lived many days longer than their sisters. This made the tails of the mortality distribution long, and probably accounted for most of the significance in the lack-of-fit tests.

Table I. Twenty four hour mortality and average mortality at 8 days and 14 days exposure (DOT) for various essential oils and organic acids fed to honey bees, together with the total number of bees tested (sum of all replicates and dosages).

\begin{tabular}{|c|c|c|c|c|}
\hline \multirow{3}{*}{$\begin{array}{l}\text { Potential } \\
\text { Medicament }\end{array}$} & \multirow{3}{*}{$\begin{array}{l}\text { Day I } \\
\text { Average } \\
\% \text { mortality }\end{array}$} & \multicolumn{2}{|c|}{ Average \% mortality } & \multirow{3}{*}{$\begin{array}{l}\text { Number } \\
\text { of Bees } \\
\text { Tested } \\
\end{array}$} \\
\hline & & 8 DOT & |4DOT & \\
\hline & & 1000 ppm & 100,000 ppm & \\
\hline Amygdalin & 0 & $79^{* * *}$ & & 221 \\
\hline Cineole & 2 & 11 & & 214 \\
\hline Clove oil & 3 & 28 & 96 & 927 \\
\hline Control - fed & I & 10 & 40 & 1189 \\
\hline Control - unfed & 46 & $100^{* * *}$ & $100^{* * * *}$ & 495 \\
\hline Formic acid & । & 33 & 100 & 1438 \\
\hline Marjoram oil & 2 & 34 & & 308 \\
\hline Menthol DL & । & 25 & & 256 \\
\hline Menthol L & । & 21 & & 239 \\
\hline Oregano oil & I & 41 & 92 & 953 \\
\hline Oxalic acid & 6 & 96 & 100 & 1217 \\
\hline Sage oil & 3 & 21 & 87 & 1289 \\
\hline Thymol & 8 & 43 & & 201 \\
\hline Wintergreen & I & 24 & 99 & 1308 \\
\hline
\end{tabular}

\footnotetext{
"Cells with missing data are left blank." Dosage for amygdalin was 2250 ppm." All bees were dead in 4 days.
} 
Table 2. Estimated $\mathrm{LT}_{50}$ for potential medicaments at $1000 \mathrm{ppm}$. In this analysis, data from tests I and 2 were combined to estimate the $\mathrm{LT}_{50}$. Except as noted, all terms in the models were significant $(\alpha \leq 0.0 \mathrm{I})$, and all lack-of-fit tests were also significant $(\alpha \leq 0.0 \mathrm{I})$.

\begin{tabular}{|c|c|c|c|c|}
\hline Material & Molarity" & $\begin{array}{l}\mathbf{L T} T_{50} \\
\text { in days }\end{array}$ & $\begin{array}{l}\text { Lower } 95 \% \\
\text { Fudicial } \\
\text { Limit } \\
\end{array}$ & $\begin{array}{l}\text { Upper } 95 \% \\
\text { Fudicial } \\
\text { Limit } \\
\end{array}$ \\
\hline Amygdalin" & 0.0049 & 4.6 & 3.0 & 6.3 \\
\hline Cineole & 0.0065 & NS & & \\
\hline Clove Oil & & 11.2 & 10.2 & 12.8 \\
\hline Controls - Fed & & 17.0 & 15.9 & 18.7 \\
\hline Controls - unfed & & 1.9 & 1.7 & 2.1 \\
\hline Formic Acid & 0.0217 & 11.8 & 8.1 & 30.3 \\
\hline Marjoram Oil & & 27.0 & 15.0 & 3935.0 \\
\hline Menthol & 0.0064 & NS & & \\
\hline Oregano Oil & & 10.8 & 9.9 & 12.1 \\
\hline Oxalic Acid & 0.0111 & 4.8 & 2.6 & 5.9 \\
\hline Sage Oil & & 11.5 & 10.6 & 12.7 \\
\hline Thymol & 0.0067 & NS & & \\
\hline Wintergreen & 0.0029 & 14.4 & 12.6 & 17.7 \\
\hline
\end{tabular}

NS = no significant model. Mortality in these tests did not reach 50\%, so accurate estimates cannot be made.

"These plant extracts are blends of several compounds so it is not possible to calculate the molarity of each component.

"* Amygdalin concentration was 2,250 ppm, the lowest concentration tested by Kevan and Ebert (2005).

Table 3. Estimated LD 50 for the tested essential oils and organic acids at 8 Days exposure (DOT).

\begin{tabular}{|lccc|}
\hline Material & $\begin{array}{l}\text { LD } \\
\text { in } \mathbf{~ p p m ~}\end{array}$ & $\begin{array}{l}\text { Lower 95\% } \\
\text { Fudicial } \\
\text { Limit }\end{array}$ & $\begin{array}{l}\text { Upper 95\% } \\
\text { Fudicial } \\
\text { Limit }\end{array}$ \\
\hline Amygdalin & 1600 & 1300 & 1800 \\
Clove Oil & 7800 & 2300 & 18100 \\
Formic Acid & 5600 & 3500 & 8100 \\
Oregano Oil & 14900 & 0 & 43400 \\
Oxalic Acid & NS & & 21700 \\
Sage Oil & NS & 8500 & \\
Wintergreen & 13500 & & \\
\hline
\end{tabular}

NS = model non-significant $(\alpha \leq 0.01)$. Oxalic acid was too toxic and mortality by Sage Oil was too variable.

Table 4. LD 50 values 14 days exposure (DOT).

\begin{tabular}{|lllll|}
\hline Material & $\begin{array}{l}\text { LD } \\
\text { in }\end{array}$ & $\begin{array}{l}\text { Standard } \\
\text { Error of } \\
\text { Log }_{10} \text { (dose) }\end{array}$ & $\begin{array}{l}\text { Lower 95\% } \\
\text { Fudicial } \\
\text { Limit }\end{array}$ & $\begin{array}{l}\text { Upper95\% } \\
\text { Fudicial } \\
\text { Limit }\end{array}$ \\
\hline Clove Oil & 240 & 0.1483 & 80 & 710 \\
Formic Acid & 450 & 0.0653 & 280 & 720 \\
Oregano Oil & 600 & 0.1327 & 230 & 1620 \\
Oxalic Acid & 80 & 0.0635 & 50 & 130 \\
Sage Oil & NS & & 500 & 1270 \\
Wintergreen & 800 & 0.0632 & & \\
\hline
\end{tabular}




\section{Discussion}

Looking at mortality in Table I, we conclude that wintergreen, menthol, sage oil, and cineole all are relatively innocuous, and that marjoram oil is quite benign. At the other extreme, oxalic acid and, as expected, amygdalin were the most toxic, and has the potential to cause high levels of mortality if the dosage is high.

These results also demonstrate that development of hive treatment protocols require balancing the exposure time and the dose given to the hive. Our results are sufficient for dosing bees for up to 14 days, but we expect that dosage would have to be more limited if the exposure period is lengthened. If continuous dosing is the best treatment option, then additional research would be needed to assess toxicity during the over-wintering period and the effects these products may have on egg laying viability of the queen, and development of larvae. However, all of these products have a low enough toxicity that they could be used as ingested medicines (rather than fumigants) with minimal effects on the hive. Clearly, the next phase is to determine if safe doses of these products can be fed to bees to effectively manage hive pests, and whether it is better to shock the hive with a short term massive dose, or to try long term exposures at low dosages.

We would like to caution readers that these results are most relevant to adult worker health. It is possible that the adult workers could feed the medicaments to larvae, and that the larvae may be more sensitive. It is also possible that the medicaments fed to the queen or drones could affect their reproductive capacity. However, exposure of these individuals is buffered through the workers. Unless the only source of food for the entire hive is the treated sugar water, there will be a dilution effect where the treated sugar water is mixed in the hive with nectar from outside sources. A queen that gets one drop of treated syrup from one worker followed by a droplet of nectar from outside the hive is effectively consuming a nectar at half the dosage of the treated syrup. Consequently, workers will be exposed to greater dosages of these medicaments than will other members of the hive. Therefore, testing the toxicity of the medicaments to the workers is a natural first step, and it may be the only necessary step unless other problems occur as these products are developed.

\section{Acknowledgements}

We thank SBIR (Small Business Innovation Research) of the United States Department of Agriculture for support to Robert A. Stevens and Betterbee Inc. (Greenwich, NY). Alison Skinner and team of the Ontario Beekeepers' Association assisted with bee wrangling and technical instruction. Jim Tew and the Ohio State University Honey bee Lab supplied the bees for the research in Wooster. Rebecca Ebert provided additional laboratory support in Wooster.

\section{References}

AMRINE, J; NOEL, B; MALLOW, H; STASNY, T; SKIDMORE, R. (1996) Results of research using essential oils for honey bee mite control. 6pp. http://www.wvu.edu/ agexten/varroa/oils.htm

CHORIANOPOULOS, N; KALPOUTZAKIS, E; ALIGIANNIS, N; MITAKU, S; NYCHAS, G; HAROUTOUNIAN, S A (2004) Essential oils of Satureja, Origanum, and Thymus species: chemical composition and antibacterial activities against food borne pathogens. Journal of Agricultural Food Chemistry 52: $8261-8267$.

IMDORF, A; BOGDANOV, S; IBANEZ O; CHOA, R; CALDERONE, N W (1999) Use of essential oils for the control of Varroa jacobsoni Oud. in honey bee colonies. Apidologie 30: 209-228.

KEVAN, S D; KEVAN, P G (1997) Protecting bees from tracheal mites: a novel approach. American Bee Journal I37: |49-150.

KEVAN, S D; NASR, M E; KEVAN, P G (1999) Feeding menthol to honey bees (Hymenoptera: Apidae): Entry and persistence in the haemolymph without causing mortality. Canadian Entomologist 131:279-281.

KEVAN, S D; NASR, M E; KEVAN, P G; TREVINO, J D (2003) Microencapsulated medicines for beneficial insects. In Downer, R A; Mueninghoff, J C; Volgas, G G (eds) Pesticide formulations and delivery systems: meeting the challenges of the current crop protection industry. ASTM International, West Conshohocken, PA; pp. 154-162.

KEVAN, P G; EBERT, T A (2005) Can almond nectar and pollen poison honey bees? American Bee Journal 145: 507-509.

KULINCEVIC, J M; ROTHENBUHLER, W C (1973) Laboratory and field measurements of hoarding behaviour in the honey bee (Apis mellifera L.). Journal of Apicultural Research 12: 179-182.

NOWIERSKI, R M; ZENG, Z; JARONSKI, S; DELGADO, F; SWEARINGEN, W (1996) Analysis and modeling of time-dose-mortality of Melanoplus sanguinipes, Locusta migratoria migratorioides, and Schistocerca gregaria (Orthoptera: Acrididae) from Beauveria, Metarhizium, and Paecilomyces isolates from Madagascar. Journal of Invertebrate Pathology 67: 236-252.

PITAROKILL, D; COULADIS, M; PETSIKOS-PANAYOTAROU, N; TZAKOU, O (2002) Composition and antifungal activity on soil-borne pathogens of the essential oil of Salvia sclarea from Greece. Journal of Agricultural Food Chemistry 50: 6688-669l.

PREISLER, H K; ROBERTSON, J L ( 1989) Analysis of time-dose-mortality data. Journal of Economic Entomology 82: 1534-1542.

SCOTT-DUPREE, C D; OTIS, G W (1992) The efficacy of four miticides for the control of Acarapis woodi (Rennie) in a fall treatment program. Apidologie 23: 97-106. 